\title{
Treatment of Organic Livestock with Medicinal Plants: A Systematic Review of European Ethnoveterinary Research
}

\author{
Maria Mayer ${ }^{a}$ d $\quad$ Christian R. Vogl $^{\mathrm{b}} \quad$ Michele Amorena ${ }^{\mathrm{a}} \quad$ Matthias Hamburger $^{\mathrm{c}}$ \\ Michael Walkenhorst ${ }^{d}$ \\ ${ }^{a}$ Faculty of Bioscience and Agri-Food and Environment Technologies, University of Teramo, Teramo, Italy \\ ${ }^{b}$ Division of Organic Farming, Department of Sustainable Agricultural Systems, University of Natural Resources and Life Sciences \\ (BOKU), Vienna, Austria \\ ${ }^{c}$ Institute of Pharmaceutical Biology, Department of Pharmaceutical Sciences, University of Basel, Basel, Switzerland \\ dDepartment of Livestock Science, Research Institute of Organic Agriculture, Frick, Switzerland
}

\section{Keywords}

European ethnoveterinary research .

Organic livestock · Medicinal plants · Veterinary phytotherapy

\section{Summary}

Background: The EC Regulation for Organic Farming states that organic livestock should be treated preferably with phytotherapeutic products. In spite of the high importance of organic livestock in Europe, primarily ruminants, today almost no phytotherapeutic product is registered for livestock. Also, scientific information regarding veterinary phytotherapy is rare. The aim of this paper is to find approaches to cope with health problems of organic ruminants in Europe on the basis of findings from the European ethnoveterinary medicine (EuEVM). Methods: A systematic review of ethno-biomedicinal papers was conducted with the aid of the Scopus database, and 75 papers, from European countries were analyzed regarding ethnoveterinary information. Results: A total of 590 plant species referring to 102 different plant families are reported to be used for animal treatment, with Asteraceae, Fabaceae and Lamiaceae being the most important families. The traditional use of some plant species (e.g. mallow, chamomile, wormwood) corresponds with findings from recent scientific literature. The large number of less studied plant species, such as white lupin as an antiparasitic herb, and Helleborus spp. as potential immunostimulatory agent, opens an interesting field for future research. Conclusions: In general, EuEVM provides interesting treatment approaches for gastrointestinal and dermatological disorders as well as parasitosis. Findings regarding disorders of female genital or respiratory tract are less consistent. Nevertheless, EuEVM offers a solid basis for stimulating research in veterinary phytotherapy in Europe with a perspective to solve animal health problems in organic or even nonorganic ruminant production.

\section{Schlüsselwörter}

Europäische ethnoveterinärmedizische Forschung .

Ökologische Tierhaltung · Arzneipflanzen · Veteriärphytotherapie

\section{Zusammenfassung}

Hintergrund: Die EU-Verordnung zur biologischen Landwirtschaft fordert explizit den vorzüglichen Einsatz der Phytotherapie zur Therapie von Nutztiererkrankungen. Ungeachtet der großen Bedeutung der europäischen Biotierhaltung, insbesondere der Haltung von Wiederkäuern, sind aktuell kaum noch pflanzliche Arzneimittel für Nutztiere erhältlich. Darüber hinaus sind wissenschaftliche Informationen zur Veterinärphytotherapie rar. Das Ziel unserer Studie ist es, auf Basis von Erkenntnissen der europäischen Ethnoveterinärmedizin (EuEVM) Ansätze zur Lösung von Tiergesundheitsproblemen von Wiederkäuern im europäischen Biolandbau zu finden. Methoden: Auf Basis einer Kennwortsuche via der Scopus-Datenbank wurden ethnobiologische, ethnopharmakologische und ethno(-veterinär-)medizinische Peer-Review-Publikationen ermittelt und eine systematische Übersicht erstellt. Insgesamt enthielten 75 Publikationen ethnoveterinärmedizinische Informationen aus europäischen Ländern. Ergebnisse: In den ausgewerteten Publikationen wurden insgesamt 590 Pflanzenarten aus 102 Pflanzenfamilien zur Behandlung von Tieren beschrieben. Asteraceae, Fabaceae und Lamiaceae wurden hierbei als Pflanzenfamilien am häufigsten genannt. Bei einigen Pflanzenarten (z.B. wilde Malve, Kamille oder Wermut) bestand eine gute Übereinstimmung der beschriebenen traditionellen Anwendung mit der aktuellen wissenschaftlichen Literatur. Eine große Zahl bisher weniger intensiv untersuchter Pflanzenarten bietet ein breites Spektrum für zukünftige Forschung. Beispiele hierfür könnten die weiße Lupine zum antiparasitären Einsatz sowie Heleborus ssp. als potenzielle Immunstimulanzien sein. Schlussfolgerung: Die EuEVM bietet interessante Ansatzpunkte zur Behandlung von Magen-/Darm- und Hautkrankheiten sowie von Parasitosen. Weniger eindeutig waren die Resultate hinsichtlich der Anwendung von Arzneipflanzen zur Behandlung des weiblichen Genitale oder der Atemwege. Nichtsdestotrotz bietet die EuEVM eine gute Basis dafür, Forschungsarbeiten im Bereich der Veterinärphytotherapie anzuregen, woraus sich die Perspektive ergibt, einen Beitrag zur Lösung von Tiergesundheitsproblemen bei Wiederkäuern nicht nur für den europäischen Biolandbau zu leisten.

\section{KARGER \\ Fax +497614520714

Dr. med. vet. Michael Walkenhorst

Department of Livestock Science

Research Institute of Organic Agriculture

Ackerstrasse 113, 5070 Frick, Switzerland

michael.walkenhorst@fibl.org 


\section{Introduction}

Sales of organic products continue to rise, with an actual global demand 170 times higher than 10 years ago [1]. Organic agriculture is practiced in 160 countries on a total of 37.2 million hectares of agricultural land worldwide (0.86\%), with $29 \%$ being in Europe $(5.4 \%$ of all European agricultural land). Detailed data concerning European organic livestock are still lacking [1]. However, out of all organic livestock, cattle and sheep are the most important species, with nearly $3 \%$ of the total EU livestock population [2]. Organic pigs represented lower proportions, with less than $1 \%$ of the total EU livestock in most of the EU member states [2].

As in non-organic production, mastitis, metabolic disorders, endo- and ectoparasitites (especially in young stock) are major problems in organic dairy or beef herds [3-5]. Also, claw and sole disorders, such as interdigital phlegmon, acute soul haemorrhage, and sole ulcers constitute major problems in organic and non-organic dairy herds $[4,6]$. In sheep production parasitism seems to be the main problem, at least in young animals $[3,4,7]$.

Considering the high amount of veterinary antimicrobials used each year to treat livestock in EU (4,802 tonnes of active ingredient) [8], and the possibility of cross-resistance between human and animal pathogens $[9,10]$, alternatives to treat veterinary infectious diseases such as diarrhoea and respiratory afflictions are urgently needed.

Medicinal plants may be considered as one of the most important alternatives to treat organic livestock. The EC Regulation for Organic Farming states that 'phytotherapeutic products (...) shall be used in preference to chemicallysynthesized allopathic veterinary treatment or antibiotics' [11]. Nevertheless, allopathic drugs like antimicrobials and antiparasitics are still used in organic farming, with certain restrictions requested by the EC Regulation for Organic Farming and with considerable economic losses due to the doubled withdrawal period $[12,13]$. Reliable and scientifically sound alternatives are largely lacking at the moment [14, 15].

Very few phytotherapeutic products are currently registered for the treatment of livestock. Nowadays, scientific literature relies on few books or manuals regarding veterinary phytotherapy [16, 17], but clinical data on animals are few, and many applications have been adapted from human phytotherapy [16]. Further sources of information might be historical books or ethnoveterinary knowledge from Asia and Africa where medicinal plant use has a continued tradition in veterinary medicine, and findings of recent ethnoveterinary research in Europe [18]. According to McCorkle [19], ethnoveterinary research is 'the systematic investigation and application of folk veterinary knowledge, theory and practice'. The traditional use of plants has been investigated in some parts of Europe [20-25]. Homemade herbal remedies, handed down over generations, may be a useful therapeutic alternative for treatment of livestock [9, 22, 26, 27], in particular on certified organic farms [24, 27, 28]. Although there are reviews regarding ethnoveterinary medicine (EVM) from other parts of the world [20,29] and from European ethnomedicine [30], a comprehensive overview on EVM in Europe is still lacking.

Taking into account the ruminant-focused structure of European organic livestock production, main health problems, and the reasons for the use of antimicrobials and antiparasitics, the aim of our paper is to analyze previous findings from EVM research regarding treatment of inflammatory and infectious diseases (concerning respiratory and gastrointestinal tract and female genital tract including mastitis), claw disorders, and parasitosis of ruminants.

\section{Material and Methods}

\section{Selection of Scientific Publications}

This review was based upon field studies conducted in European countries, published in peer-reviewed journals between 1990 and 2013, and indexed by Scopus [30]. The search terms were selected from keyword indices of major ethnomedicinal/ethnobotanical journals (Journal of Ethnopharmacology, Journal of Ethnobiology and Ethnomedicine), matched with the Scopus search fields 'abstract', 'title', 'keywords', and 'text' (ethno* OR tradition* OR folk) AND (veterinar* OR animal OR livestock OR farm* OR sheep OR goat OR cattle OR cow OR pig OR calv* OR poultry) AND (plant OR herb* OR phyto*), and with each country of the EU, including candidate and affiliated countries (Albania, Austria, Belgium, Bosnia and Herzegovina, Bulgaria, Croatia, Cyprus, Czech Republic, Denmark, Estonia, Finland, France, Germany, Greece, Hungary, Kosovo, Iceland, Ireland, Italy, Latvia, Lithuania, Luxembourg, Malta, Montenegro, Netherlands, Poland, Portugal, Romania, Serbia, Slovakia, Slovenia, Spain, Sweden, Switzerland, the former Yugoslav Republic of Macedonia, Turkey, United Kingdom). From this first search 8,822 titles were extracted, which were reduced to a final set of 75 publications [20-23, 32-102] by a 2-step process (fig. 1) on the basis of a set of predefined criteria: The first selection was based on headlines and abstracts, the following on the entire paper. We only considered ethnoveterinary, ethnopharmacological, ethnomedicinal, and ethnobotanical papers containing information on at least 1 plant species which was unambiguously linked to a veterinary use. Information from review papers were only included if they did not refer to papers already included in our search. Zootherapeuticals as well as plant species which were reported to be toxic or main components of the basic ration were not included in our dataset.

\section{Data Collection}

From each paper, we collected - if available - the following information on plant species unambiguously directed to veterinary use: 1) Plant parts used (aerial part, bark, branches/stems, flower, flowered aerial part, fruits/seeds/berries, leaves, roots/bulb, whole plant, whole plant without roots, others); 2) Animal species treated; 3) Age classification of the treated animal (adult, young); and 4) Therapeutic use. Animals are reported at species level, except for 'equine' (horse, mule, asses) and 'poultry' (lying hens and broilers, turkeys). The term 'cattle' included also oxen and buffalos, while 'small ruminants' included sheep and goats. For the classification of the indication we used the Anatomical Therapeutic Chemical Classification System for veterinary medicinal products (ATCvet) [103]. Beside the ATCvet code, we followed the concept of 'food as medicine' [104] embracing any feed additive if it was clearly directed to one or more animal species. If no information for one of the categories mentioned above could be found, we classified it as 'information not available'. 


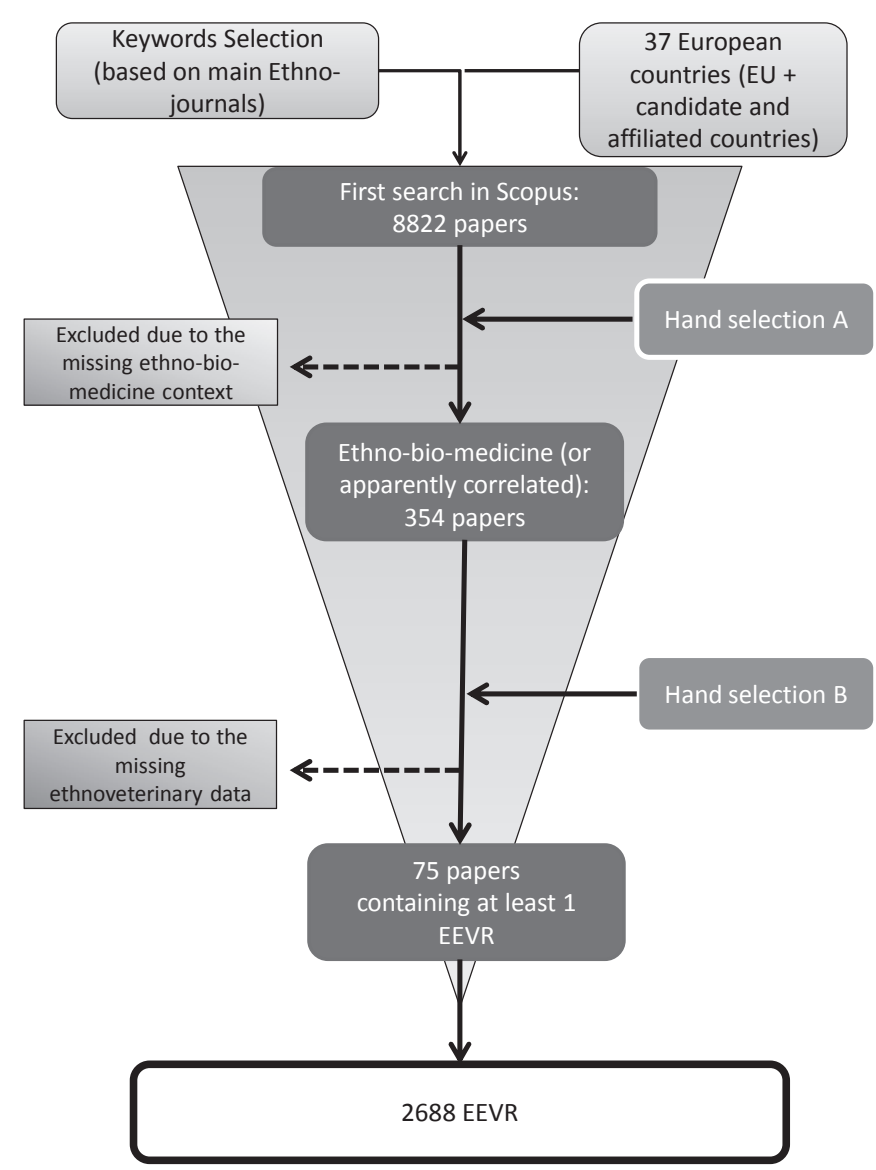

Fig. 1. Process of paper selection. Hand selection A: Selection based on headlines and abstracts; Hand selection B: Selection based on the entire paper. Papers including at least one plant species unambiguous connected to a veterinary use were presented; EEVR = European Ethnoveterinary use Reports.

Plants family assignment followed the APG III classification (Angiosperm Phylogeny Group III) [105], and subspecies were included where applicable. Abbreviations for country names were according to ISO 3166 -1 alpha-2 codes [106]

\section{Definition of European Ethnoveterinary use Reports (EEVR)}

In our outcomes each individual combination ((mandatory: 'scientific paper' $\mathrm{x}$ 'plant species unambiguously directed to veterinary use') $\mathrm{x}$ (if available: 'plant part used' $\mathrm{x}$ 'animal species treated' $\mathrm{x}$ 'age classification of the animal' $\mathrm{x}$ 'ATCvet code indication' $\mathrm{x}$ 'ATCvet sub-code indication')) was denominated as one EEVR. For example, if a Malva sylvestris L. infusion of leaves was described for dermatological use in adult cattle in one study, it was considered a different EEVR than administered on another animal species or the same animal species but different age in the same study. The same applied for a different plant part of the same plant species.

\section{Results}

Ethnoveterinary data are available for 12 of the 37 European countries included in the survey. The most comprehensive data were available from Italy, Spain, and Turkey (fig. 2).
In total we identified 2,688 EEVR (appendix I; table 1; www. karger.com/doi/10.1159/000370216).

\section{Reported Plants}

A total of 590 plant species referring to 102 different plant families were reported to be used for animal treatment. Asteraceae, Fabaceae and Lamiaceae were most relevant families with more than 100 EEVR each. The 10 most often mentioned plant species represented $16 \%$ of total EEVR: Malva sylvestris L. (83 EEVR, 3\%), Vitis vinifera L. (70 EEVR, 3\%), Urtica dioica L. (50 EEVR, 2\%), Allium sativum L. (43 EEVR, 2\%), Olea europeae L. (37 EEVR, 1\%), Sambucus nigra L. (34 EEVR, 1\%), Matricaria chamomilla L. (33 EEVR, 1\%), Hypericum perforatum L. (29 EEVR, 1\%), Fraxinus ornus L. (28 EEVR, 1\%), Scrophularia canina L. (28 EEVR, 1\%); appendix II; www.karger.com/doi/10.1159/000370216).

Plant parts most frequently applied were aerial parts (391 EEVR), followed by leaves (370 EEVR), fruits, seeds, and berries (309 EEVR). However, in almost one third of cases (858 EEVR) no plant part was described.

\section{Treatments of Animals}

The most frequently treated animals were ruminants in general (1,115 EEVR, 44\% of total EEVR) including cattle (652 EEVR), small ruminants (441 EEVR), and not specified ruminants (22 EEVR). The following animal species treated were equine (290 EEVR, 11\%), pigs (188 EEVR, 7\%), poultry (162 EEVR, 6\%), and rabbits (93 EEVR, 3\%). The category of 'other' (total of 98 EEVR, 4\%) included all other livestock species, plus dogs and cats. In one quarter of use reports the treatment was not explicitly directed to a specific animal species (684 EEVR, 25\%).

In $97 \%$ of EEVR, the age of target animal species was not explicitly reported. In particular, 90 EEVR were reported explicitly for young and 5 EEVR for adult animals.

We focused mainly on EEVR closely linked to a classification according to the ATCvet code (EEVRT: 1931; appendix II + appendix III; www.karger.com/doi/10.1159/000370216), excluding feed additives (347 EEVR), not further specified veterinary indications (313 EEVR), and indications that were not clearly connected to an ATCvet code (126 EEVR).

In the finally selected papers, 1,931 EEVRT could be related to 11 different ATCvet codes: The indication of alimentary tract and metabolism (QA) was addressed by 532 EEVRT (28\%), dermatologicals (QD) by 441 EEVRT (23\%), and genitourinary system and sex hormones (QG) by 308 EEVRT (16\%). These 3 codes represented about two thirds of all EEVRT (fig. 3). Approximately half of the EEVRT were also related to a more specific subcode of ATCvet (1023 EEVRT, 53\%). Most frequently cited plants related to our main indications and subindications are summarized in table 2 (www.karger.com/doi/10.1159/ 000370216). 


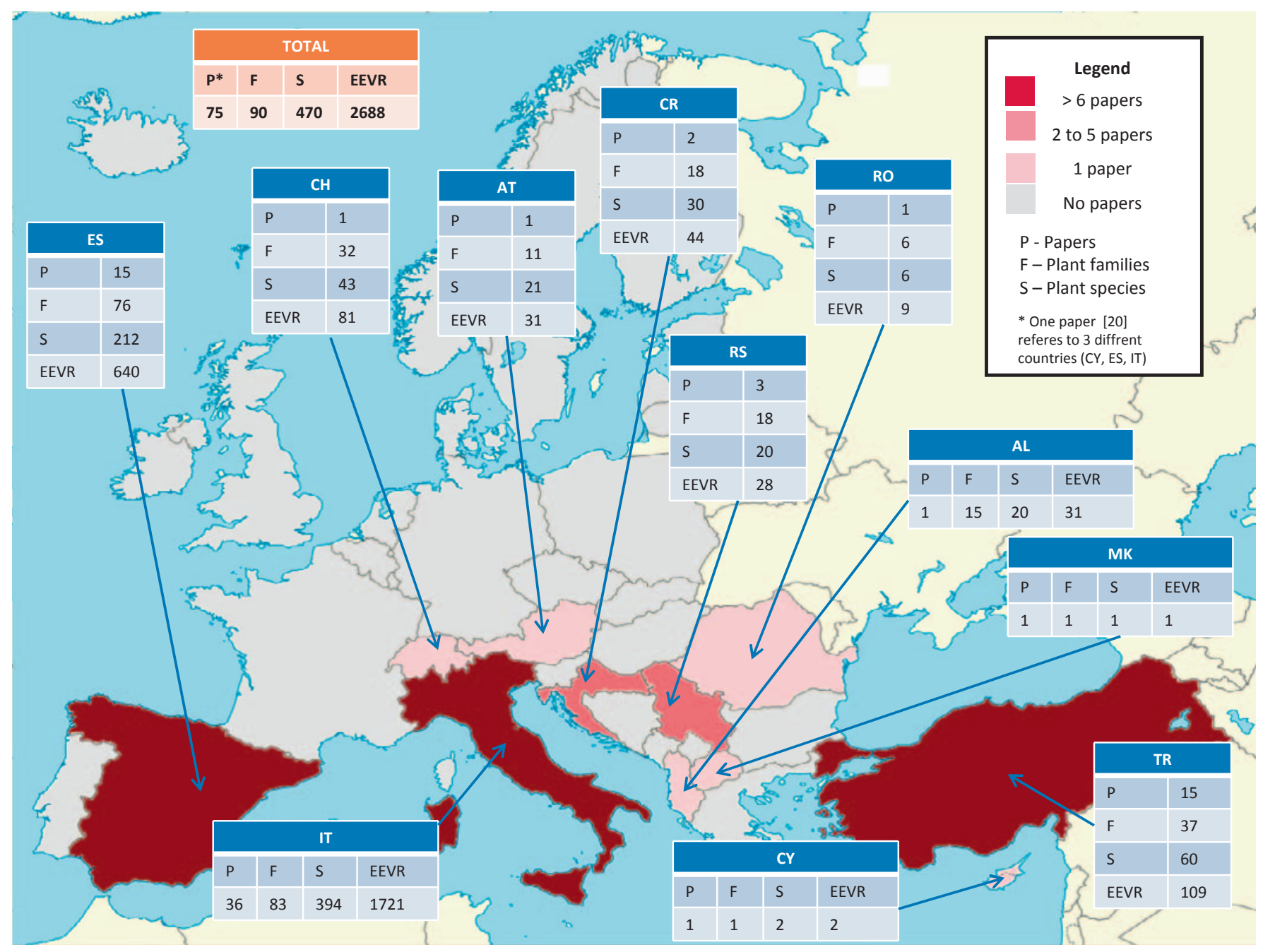

Fig. 2. European map of ethnoveterinary research. $\mathrm{AL}=\mathrm{Albania} ; \mathrm{AT}=$ Austria; $\mathrm{CH}=$ Switzerland; $\mathrm{CR}=\mathrm{Croatia} ; \mathrm{CY}=\mathrm{Cyprus} ; \mathrm{RO}=\mathrm{Romania}$; IT = Italy; MK = Macedonia; RS = Serbia; TR = Turkey.

\section{Discussion}

Considering the growing importance of European organic livestock production, in particular ruminants, and the priority of phytotherapy for the treatment of organic livestock [1, 2, 107], solutions might be found in EuEVM. Surveys with more or less extensive ethnoveterinary information have been conducted only for a small number of European countries. A total of 2,688 EEVR were extracted from 75 original papers. 1,931 of them contained therapeutic indications (EEVRT), which were classified according to ATCvet. In our review, we focused diseases with a high relevance for organic ruminants, and/or closely connected to the use of antimicrobials and antiparasitics, namely infectious diseases of gastrointestinal, respiratory, and female genital system (including mastitis), claw disorders, and parasitosis.

Even if, according to Quave et al. [30], some less accessible studies could be important for the understanding of local traditional knowledge, we analyzed only peer-reviewed papers written in English, since they represent widely accessible knowledge for the scientific community, veterinarians, and pharmaceutical companies. However, we are aware that also nonscientific or scientific but not English sources can contain ethnoveterinary information. Maybe further reviews will focus particularly on these sources.

Among European countries, Italy is strongly represented in this survey, with a total of 38 papers and almost two third of all EEVR, while other countries are represented by only 1 paper (AT, AL, CH, CY, HU, MK) and, in some cases, by a single EEVR (MK). This underlines the necessity of further ethnoveterinary research, in particular in Central Northern, and Eastern Europe.

Due to the broad spectrum of study designs and inconsistent or even missing data, detailed information regarding the use of medicinal plants for veterinary purpose were not available in most publications. Even though preparation and way of administration might influence therapeutic efficacy strongly, these information are reported only fragmentary and incon- 
Fig. 3. Distribution of European Ethnoveterinary use Reports (EEVR) according to veterinary therapeutic indications of the Anatomical Therapeutic Chemical Classification system for veterinary medicinal products (EEVRT). ATCvet codes: $\mathrm{QA}=\mathrm{Ali}-$ mentary tract and metabolism; QC = Cardiovascular system; $\mathrm{QD}=$ Dermatologicals; $\mathrm{QG}=$ Genito urinary system and sex hormones; QJ = Antiinfectives for systemic use; $\mathrm{QL}=$ Antineoplastic and immunomodulating agents; $\mathrm{QM}=$ Musculoskeletal system; $\mathrm{QN}=$ Nervous system; $\mathrm{QP}=$ Antiparasitic products, insecticides, and repellents; $\mathrm{QR}=$ Respiratory system; QS = Sensory organs. In brackets = Number of EEVRT per ACT vet code; percentage referred to a total of 1,931 EEVRT.

sistent for less than a half of EEVR. Only a few papers are focused on EVM [22, 35, 37, 38, 42, 52, 57, 81, 98, 101]. Since ethno-biomedical surveys are conducted usually in rural areas where farm animals are likely, future investigations should provide detailed information regarding veterinary treatment in order to enrich European ethnoveterinary knowledge.

From the plant species reported in the surveyed publications, in the following we discuss selected, very common (high number of EEVRT) and/or widely used (high number of referring papers or countries) plants for important ATCvet codes (alimentary tract and metabolism (QA), drugs for functional gastrointestinal disorders (QA03), antidiarrheals, intestinal anti-inflammatory/antiinfective agents (QA07), dermatologicals (QD), preparations for treatment of wounds and ulcers (QD03), products for the treatment of claws and hoofs (QD51), genitourinary system and sex hormones (QG), gynecological antiinfectives and antiseptics (QG01), products for teats and udder (QG52), antiparasitics, insecticides and repellents (QP), anthelmintics (QP52), ectoparasiticides, insecticides and repellents (QP53), and respiratory system (QR)) to discuss the significance of their use in the context of current pharmacological knowledge, human and veterinary clinical trials, and empirical studies (table 3; www.karger.com/ doi/10.1159/000370216).

\section{Gastrointestinal Disorders (QA - 532 EEVRT, 60 Plant Families, 205 Plant Species)}

Diseases of the gastrointestinal tract were the main focus of EuEVM, with $28 \%$ of all EEVRT. Malva sylvestris L. (26 EEVRT), Vitis vinifera L., and Matricaria chamomilla L. were the most widely used species. Vitis vinifera L. is not discussed further, given the difficulties of distinguishing between its use as herbal drug, alcoholic product, or source for vinegar due to its acidic properties. We mainly focused functional gastrointestinal disorders (QA03), antidiarrheals, and intestinal antiinflammatory/antiinfective agents (QA07).

\section{Mallow (Malva sylvestris $L$.)}

Mucilaginous heteropolysaccharides are the major components responsible for therapeutic effects of mallow and are found mainly in leaves $(6.0-7.2 \%)$, flowers $(3,8-7,3 \%)$, and roots $(7,5 \%)$ [107]. Leaves and aerial parts were mostly administered orally and considered helpful in case of various digestive disturbances, such as abdominal colic, tympanism, for reactivation of rumination in small and large ruminants, generic digestive problems, diarrhoea, and constipation. In a total of 12 Italian and Spanish publications, mallow was often referred to as functional gastrointestinal (QA03) agent for ruminants (6 EEVRT) and as general gastrointestinal (QA) agent (26 EEVRT). Mallow is a well-known medicinal plant, but its use in livestock and especially in rumen complaints should be further investigated.

\section{Chamomile (Matricaria chamomilla L.)}

The major constituents of chamomile flowers are a sesquiterpene-containing essential oil and flavones [109]. Chamomile flowers and aerial part were used in EuEVM mainly as decoction or infusion for the treatment of digestive problems in livestock and colic pain. The use is corroborated by scientific literature and veterinary phytotherapy text books and manuals $[16,17,109]$. However, no scientific data are available regarding its administration in ruminants; clinical research would be helpful to establish effective dosages.

\section{Other Plants}

Apart from Mercurialis annua L. which is traditionally used as an anti-constipation agent, probably due to its toxic properties [110], several plant species seem to be promising gastrointestinal (QA) agents.

EuEVM plants, such as wormwood (Artemisia absinthium L.), elderberry (Sambucus nigra L.), yarrow (Achillea millefolium L.), and lineseed (Linum usitatissimum L. seeds), may be effective for the treatment of gastrointestinal disorders, such as colic, impaired digestion, tympany, and meteorism. On the one hand, they are already well-known in human phytotherapy for treatment of similar complaints [109] and, on the other hand, some of these plants have also been mentioned in veterinary phytotherapy text books and manuals [16, 17]. Application of yarrow has been reported in 4 different countries (ES, IT, RO, RS). These reports are corroborated by pharmacological and human clinical research [111-113]. This herbal drug could be considered as a functional gastrointestinal (QA03) and possibly antidiarrheal, intestinal antiinflammatory/antiinfective (QA07) agent. 
However, pharmacological data regarding possible use in the context of gastrointestinal disorders are lacking for some plants, such as for Salix alba L. (mainly branches and leaves). According to EuEVM reports from Turkey and Italy, chewing of willow by sheep increases salivary production [114], which in turn could lead to reactivation of rumination. However, these reports need to be substantiated by further pharmacological research. The same applies for garlic (Allium sativum L.), most commonly known as antiparasitic (QP), but reported from EVM in Italy also as gastrointestinal (QA) agent. Garlic was recently tested in sheep for improvement of digestion [115], but more basic research is needed here to substantiate this finding.

Regarding anti-diarrheals, EuEVM suggests a wide spectrum of different plants, without a consistent repetition of same species. Quercus ilex L. and Hordeum vulgare L. might be potentially useful due to their tannin content [116-118], but increased phytochemical knowledge and standardized preparations are needed for clinical trials in ruminants.

\section{Dermatological Disorders (QD - 441 EEVRT, 60 Plant Families, 190 Plant Species)}

A considerable percentage of EEVRT (23\%) was directed to dermatological diseases. It seems quite common for farmers to treat these easily visible disorders on their own without recurring to a veterinarian, which might lead to a more frequent transfer of knowledge from generation to generation. Plant species mentioned for treatment of dermatological disorders (QD), and in particularly preparations for treatment of wounds and ulcers (QD03), may also have a potential to treat claw disorders.

EuEVM reports 3 plants against cattle ringworm (QD01). Of these, Ilex aquifulium L. and Rhamnus catharticus L. seem to have a more ritual use, while Lupinus albus L. is the only plant directly applied on the skin. Although cattle ringworm is not a major veterinary problem, it remains an important zoonotic fungal infection which requires therapeutic intervention [119].

\section{Scrophularia canina $L$.}

EuEVM frequently reports this plant species for treatment of dermatological disorders, as preparation for treatment of wounds and ulcers (QD03) as well as claws and hoofs (QD51). There is little published data, and one can only speculate that iridoid glycosides as component of Scrophulariaceae may play a role as active principle [120-122].

\section{Aleppo pine resin (Pinus halepensis $L$.)}

According to recent studies [123-125], there is scientific basis for the traditional use of conifer resins for treatment of wounds and ulcers. Aleppo pine (needles, twigs, and buds) possesses antibacterial activity against different bacterial pathogens [125]. These studies may justify the use of Aleppo pine resin as preparation for treatment of wounds and ulcers (QD03), and of macerated buds for treatment of claw diseases (QD51).

\section{Other Plants}

Broadleaf plantain (Plantago major L.) was also frequently cited in EuEVM as a vulnerary drug (QD03). Books or manuals regarding veterinary phytotherapy and phytochemical research seem to corroborate its therapeutical use. Thus, a specific veterinary evaluation would be indicated since clinical research into veterinary use is still lacking $[17,126]$. The same applies for mallow and St. John's wort (Hypericum perforatum L.), which are both well-known in EuEVM and also documented in scientific literature as a vulnerary drug (QD03) [16, 108, 128-131]. Also, studies concerning treatment of claws and hoofs (QD51) should be conducted.

\section{Disorders of Female Genital and Udder ( $Q G-308$ EEVRT, 53 Plant Families, 150 Plant Species)}

Mastitis and genital internal infections occur mostly after calving, and represent a considerable economic loss for organic dairy herds, considering that the withdrawal period after a treatment with antibiotics is twice as long compared to conventional farming [107, 132-134]. Replacement by herbal preparations could be helpful. Although 62 EEVRT are referred to subcode QG52 (products for teats and udder), none of all QG plant species received a particularly high number of citations in EuEVM (appendix III; www.karger.com/ doi/10.1159/000370216).

\section{Internal Female Genital Organs}

Mallow is used in Spain as an antiinfective and antiseptic after delivery (QG01-10 EEVRT), while in Italy mallow decoction is used to expel the placenta after giving birth (QG02 - 3 EEVRT). In both cases, a decoction or infusion is orally administered to treat animals. Further research is needed to substantiate this particular use of mallow.

\section{Mastitis}

The emollient properties of mallow may justify its use as a topical agent for udder skin; its antibacterial properties are known to be effective against mastitis-causing pathogens (Staphylococcus aureus and S. agalactiae) [109, 135]. Veterinary clinical research is needed to investigate whether topical application may mitigate intramammary infection. The same is true for St. John's wort which is also topically used and possesses distinct anti-bacterial and anti-inflammatory properties $[17,136,137]$. 
Respiratory Diseases (QR - 114 EEVRT, 29 Plant Families, 67 Plant Species)

Respiratory diseases are not the main issue in organic dairy farming, but they are largely responsible for the use of antibiotics in conventional farms $[15,138]$, and in other livestock species, such as poultry and pigs [15].

Mallow and chamomile are most frequently reported in EuEVM as respiratory (QR) agents. Their use may be justified by their antimicrobial properties, but further studies should specifically address effects on the respiratory tract. In humans, inhalation of chamomile oil shows beneficial properties [139].

Widespread use of Helleborus ssp. in EuEVM is surprising if one considers the distinct toxicity of cardiac glycosides contained in the plants [140]. In Italy, Romania, Serbia, and Turkey a root or branch of Helleborus spp. is inserted under the skin of sick animals to treat respiratory problems. The use of Hellborus as an immunostimulating drug has been reported $[141,142]$, but further research is needed for this traditional use.

Antiparasitic Products (QP-278 EEVRT, 49 Plant Families, 111 Plant Species)

Annual expenditures for treatment of ruminants in Europe with anthelmintics amount to approximately EUR 53 Million [143]. Increasing resistance to current drugs requires alternative solutions both in conventional and organic farming [15]. Moreover, gastrointestinal parasites are a potentially serious threat, especially to organic sheep and goat production $[12,15]$.

\section{Garlic (Allium sativum L.)}

The effects of garlic bulbs are well-known in EuEVM (19 EEVRT). Activity on different endoparasites has been shown both in vitro and in vivo (round and flatworm, flagellates) [144-148]. Topical application of garlic also showed some activity against chicken mites [149]. Allium sativum L. is mentioned as anthelmintic (QP52) and antiprotozoal agend in a text book regarding veterinary phytotherapy [16], but more research is needed [150], particularly clinical veterinary trials.

\section{Wormwood (Artemisia absinthium L.)}

Aerial parts and leaves of wormwood are used in EuEVM against ecto- and endoparasites, mainly in cattle. In vitro and in vivo data suggest that wormwood might be effective as anthelmintic (QP52) [151, 152], but its use as ectoparasitic or repellent agent (QP53) needs to be substantiated [153].

\section{Other Plants}

EuEVM indicates some further interesting although less known antiparasitics plants: white lupin (Lupinus albus L.) and cade (Juniperus oxicedrus L.) as most promising agents against ectoparasites (QP53). Seeds of white lupins are boiled and applied onto the skin of animals, probably due the richness in alkaloids of the bitter varieties of this plant (e.g., lupanin) [154], and are reportedly effective as crop parasite repellent and aphicide [155, 156]. Cade essential oil was found to be effective against poultry red mites [157]. Cultivated tobacco (Nicotiana tabacum L.) is also used against ectoparasites (QP53). Given the pharmacological and toxicological properties of its major alkaloid, nicotine [158], further studies are needed to clarify if a safe use of this plant might be possible. Infusions of branches, leaves, and flowers of Fraxinus ornus L. are used in Italian EVM against ectoparasites and diarrhea. Anti-coccidial properties have been demonstrated in broilers [159], but the use in QP52 (anthelmintics) and QP53 (ectoparasites) indications requires further investigation. Ruta chalepensis L. and Ruta graveolens L. are used in EuEVM as antiparasitic herbs (QP - 9 EEVRT each). $R$. chalepensis is mainly used against endoparasites in ruminants (6 EEVRT). There is preliminary evidence, especially regarding their possible use against endoparasitosis (QP52) [160], but further studies are needed, in particular regarding their metabolization in rumen.

\section{Conclusion}

This systematic review highlights the relevance of research in EuEVM as a source of information regarding a diversification and substantiation of medicinal plant use in the treatment of organic livestock. Even though large areas of Europe remain to be mapped for their traditional ethnoveterinary knowledge, an impressive number of plant species has already been reported. EuEVM may provide promising and new approaches for the treatment of gastrointestinal and dermatological disorders as well as parasitosis. Regarding female genital and respiratory disorders, our findings are less consistent. For a series of plant species (e.g., mallow, chamomile, wormwood), traditional ethnoveterinary use and scientific evidence based on pharmacological and (human) clinical research corresponded very well. A number of less studied plants may offer promising starting points for future research, such as white lupin as a potential antiparasitic agent. We hope that this review will stimulate further ethnoveterinary research, particularly in central-eastern and northern Europe, and clinical research in livestock with promising plant species, in a larger effort to re-establish veterinary phytotherapy as an integral part of sustainable treatments for health problems in organic and maybe even in non-organic livestock.

\section{Disclosure Statement}

We want sincerely thank the foundation 'Dreiklang für ökologische Forschung und Bildung' for the financial support of our study. 


\section{Supplemental Material}

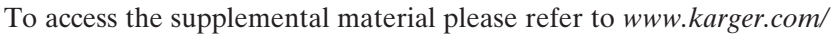
doi/10.1159/000370216.

Table 1. Therapeutic classification, medicinal plants, and target animal species of European Ethnoveterinary use Reports (EEVR)

Table 2. Plant species most frequently mentioned in European Ethnoveterinary use Reports (EEVR) linked to a classification according to the ATCvet code1 (EEVRT) and their number of referring papers and countries

Table 3. Selected plant species frequently mentioned in European Ethnoveterinary use Reports (EEVR) and their levels of pharmacological and therapeutic evidence (pharmacologic studies, in vitro and in vivo studies, human and veterinary clinical trials)
Appendix I: European Ethnoveterinary use Reports (EEVR).

Appendix II: European Ethnoveterinary use Reports (EEVR) and EEVR according to veterinary therapeutic indications of the Anatomical Therapeutic Chemical Classification system for veterinary medicinal products (EEVRT) per plant species and plant family.

Appendix III: Plant species per therapeutic indications and number of European ethnoveterinary use Reports (EEVR) according to veterinary therapeutic indications of the Anatomical Therapeutic Chemical Classification system for veterinary medicinal products (EEVRT).

\section{References}

1 Willer H, Lernoud J, Kilcher LE: The world of organic agriculture. Statistics and emerging trends 2013. FiBL-IFOAM report. Bonn, Research Institute of Organic Agriculture (FiBL), Frick, and International Federation of Organic Agriculture Movements (IFOAM), 2013.

2 Rohner-Thielen E: Area under organic farming increased by $7.4 \%$ between 2007 and 2008 in the eu-27. Eurostat. Statistics in Focus 2010;10. www.epp.eurostat.ec.europa.eu/cache/ITY_OFFPUB/KS-SF-10 010/EN/KS-SF-10-010-EN.PDF (access 01.12.14).

3 Hovi M, Sundrum A, Thamsborg SM: Animal health and welfare in organic livestock production in Europe: current state and future challenges. Livest Prod Sci 2003;80:41-53.

4 Cabaret J: Animal health problems in organic farming: subjective and objective assessments and farmers' actions. Livest Prod Sci 2003;80:99-108.

$\checkmark 5$ Valle PS, Lien G, Flaten O, Koesling M, Ebbesvik M: Herd health and health management in organic versus conventional dairy herds in Norway. Livest Sci 2007;112:123-132.

6 Ortman K, Svensson C: Use of antimicrobial drugs in Swedish dairy calves and replacement heifers. Vet Rec 2004:154:136-140.

7 Benoit M, Laignel G: Constraints under organic farming on french sheepmeat production: a legal and economic point of view with an emphasis on farming systems and veterinary aspects. Vet Res 2002;33:613-624.

8 European Medicines Agency (EMA): Sales of veterinary antimicrobial agents in 19 EU/EEA countries in 2010. www.ema.europa.eu/docs/en_GB/ document_library/Report/2012/10/WC500133532.pdf (access 01.12.14).

9 World Health Organization (WHO): Second joint FAO/OIE/WHO expert workshop on non-human antimicrobial usage and antimicrobial resistance: Management options. Oslo, WHO, 2004.

10 Marshall BM, Levy SB: Food animals and antimicrobials: impacts on human health. Clin Microbiol Rev 2011;24:718-733.

11 No authors listed: Commission implementing regulation (eu) no 505/2012 of 14 june 2012 amending and correcting regulation (ec) no 889/2008 laying down detailed rules for the implementation of council regulation (ec) no 834/2007 on organic production and labelling of organic products with regard to organic production, labelling and control. CELEX-EUR 2012;L.154:12.
12 Lund V, Algers B: Research on animal health and welfare in organic farming - a literature review. Livest Prod Sci 2003;80:55-68.

13 Bennedsgaard TW, Klaas IC, Vaarst M: Reducing use of antimicrobials - experiences from an intervention study in organic dairy herds in Denmark. LivestSci 2010;131:183-192.

14 Kijlstra A, Eijck IAJM: Animal health in organic livestock production system: a review. NJAS - Wageningen Journal of Life Sciences 2006;54:77-94.

15 Vaarst M, Lund V, Roderick S, Lockeretz W: Animal Health And Welfare In Organic Agriculture. Cambridge, CABI, 2003.

16 Wynn SG, Fougère BJ: Veterinary Herbal Medicine: A Systems-Based Approach. Saint Louis, Mosby, 2007.

17 Rabinovich MI: Medicinal Plants in Veterinary Medicine. Moscow, Russianagricolture, 1981.

18 Walkenhorst M, Vogl C, Vogl-Lukasser B, Vollstedt S, Brendieck-Worm C, Ivemeyer S, Klarer F, Meier B, Schmid K, Disler M, Bischoff T, Hamburger M, Häsler S, Stöger E: Zwischen Empirie und Evidenz - (Re)Aktivierung der Veterinärphytotherapie. Forsch Komplementmed 2014;21(suppl 1):35-42.

19 McCorkle CM: An introduction to ethnoveterinary research and development. J Ethnobiol 1986;6: 129-149.

20 Pieroni A, Giusti ME, de Pasquale C, Lenzarini C, Censorii E, Gonzáles-Tejero M, Sánchez-Rojas C, Ramiro-Gutiérrez JM, Skoula M, Johnson C, Sarpaki A, Della A, Paraskeva-Hadijchambi D, Hadjichambis A, Hmamouchi M, El-Jorhi S, El-Demerdash M, El-Zayat M, Al-Shahaby O, Houmani Z, Scherazed M: Circum-mediterranean cultural heritage and medicinal plant uses in traditional animal healthcare: a field survey in eight selected areas within the rubia project. J Ethnobiol Ethnomed 2006;2:16.

21 Bonet MA, Vallès J: Ethnobotany of montseny biosphere reserve (Catalonia, Iberian peninsula): plants used in veterinary medicine. J Ethnopharmacol 2007;110:130-147.

22 Schmid K, Ivemeyer S, Vogl C, Klarer F, Meier B, Hamburger M, Walkenhorst M: Traditional use of herbal remedies in livestock by farmers in 3 swiss cantons (Aargau, Zurich, Schaffhausen). Forsch Komplementmed 2012;19:125-136.

23 Uncini Manganelli RE, Camangi F, Tomei PE: Curing animals with plants: traditional usage in Tuscany (Italy). J Ethnopharmacol 2001;78:171-191.
24 Schunko C, Vogl CR: Organic farmers use of wild food plants and fungi in a hilly area in Styria (Austria). J Ethnobiol Ethnomed 2010;DOI:10.1186/ 1746-4269-6-17.

25 Vogl-Lukasser B, Vogl CR, Reiner H: The turnip (Brassica rapa L. subsp. rapa) in Eastern Tyrol (Lienz district; Austria). Ethnobot Res Applic 2008;5:305-317.

26 Aarestrup F, Oliver Duran C, Burch D: Antimicrobial resistance in swine production. Anim Health Res Rev 2008;9:135-148.

27 Vogl-Lukasser B, Vogl C, Bizaj M, Grasser S, Bertsch C: Lokales Erfahrungswissen über Pflanzenarten aus Wildsammlung mit Verwendung in der Fütterung und als Hausmittel in der Volksheilkunde bei landwirtschaftlichen Nutztieren in Osttirol. Wien, Department für Nachhaltige Agrarsysteme, Endbericht, 2006. www.nas.boku.ac.at/ fileadmin/data/H03000/H93000/H93300/Personen/ Vogl/1272_VOGL_Wildsammlung03042006.pdf (access 01.12.14).

28 Bizaj M: Lokales wissen von osttiroler Bäuerinnen und Bauern über Pflanzen und Hausmittel zur Gesunderhaltung und Krankheitsbehandlung ihrer Tiere und die Bedeutung für den biologischen Landbau. Institut für ökologischen Landbau, Departement für Nachhaltige Agrarsysteme. Wien, Universität für Bodenkultur, 2005, Diplomarbeit, pp 104.

29 McGaw LJ, Eloff JN: Ethnoveterinary use of southern african plants and scientific evaluation of their medicinal properties. J Ethnopharmacol 2008; 119:559-574.

30 Quave CL, Pardo-de-Santayana M, Pieroni A: Medical ethnobotany in Europe: from field ethnography to a more culturally sensitive evidence-based CAM? Evid Based Complement Alternat Med 2012;2012:17.

31 Scopus database. www.scopus.com (access 01.12.14).

32 Agelet A, Valles J: Studies on pharmaceutical ethnobotany in the region of Pallars (Pyrenees, Catalonia, Iberian Peninsula). Part I. General results and new or very rare medicinal plants. J Ethnopharmacol 2001;77:57-70.

33 Agelet A, Vallès J: Studies on pharmaceutical ethnobotany in the region of Pallars (Pyrenees, Catalonia, Iberian Peninsula). Part III. Medicinal uses of non-vascular plants. J Ethnopharmacol 2003;84: 229-234. 
34 Agelet A, Vallès J: Studies on pharmaceutical ethnobotany in the region of Pallars (Pyrenees, Catalonia, Iberian Peninsula). Part II. New or very rare uses of previously known medicinal plants. J Ethnopharmacol 2003;84:211-227.

35 Akerreta S, Calvo MI, Cavero RY: Ethnoveterinary knowledge in Navarra (Iberian Peninsula). J Ethnopharmacol 2010;130:369-378.

36 Akerreta S, Cavero RY, Calvo MI: First comprehensive contribution to medical ethnobotany of Western Pyrenees. J Ethnobiol Ethnomed 2007;3: 26.

37 Benítez G, González-Tejero MR, Molero-Mesa J: Knowledge of ethnoveterinary medicine in the province of Granada, Andalusia, Spain. J Ethnopharmacol 2012;139:429-439.

\38 Blanco E, Macía MJ, Morales R: Medicinal and veterinary plants of El Caurel (Galicia, Northwest Spain). J Ethnopharmacol 1999;65:113-124.

39 Bonet MA, Parada M, Selga A, Vallès J: Studies on pharmaceutical ethnobotany in the regions of L'Alt Emporda and Les Guilleries (Catalonia, Iberian Peninsula). J Ethnopharmacol 1999;68:145-168.

40 Bonet MÀ, Vallès J: Pharmaceutical ethnobotany in the Montseny biosphere reserve (Catalonia, Iberian Peninsula). General results and new or rarely reported medicinal plants. J Pharm Pharmacol 2003;55:259-270.

41 Bruni A, Ballero M, Poli F: Quantitative ethnopharmacological study of the Campidano valley and Urzulei district, Sardinia, Italy. J Ethnopharmacol 1997;57:97-124.

42 Bullitta S, Piluzza G, Viegi L: Plant resources used for traditional ethnoveterinary phytotherapy in Sardinia (Italy). Genet Resour Crop Evol 2007;54: 1447-1464.

43 Bulut G, Tuzlaci E: Folk medicinal plants of Bayrami ç (Çanakkale-Turkey). Journal of Pharmacy of Istanbul University 2008;40:87-99.

44 Cornara L, La Rocca A, Marsili S, Mariotti MG: Traditional uses of plants in the Eastern Riviera (Liguria, Italy). J Ethnopharmacol 2009;125:16-30.

45 Cruz GB, Mesa JM, De García MLRG: Floristic and ecological diversity of ethnobotanical resources used in Western Granada (Spain) and their conservation. Acta Botanica Gallica 2010;157:769-786.

46 De Natale A, Pezzatti GB, Pollio A: Extending the temporal context of ethnobotanical databases: the case study of the campania region (Southern Italy). J Ethnobiol Ethnomed 2009;5:7.

47 Di Novella R, Di Novella N, De Martino L, Mancini E, De Feo V: Traditional plant use in the National Park of Cilento and Vallo di Diano, Campania, Southern Italy. J Ethnopharmacol 2013;145: 328-342.

48 Di Sanzo P, De Martino L, Mancini E, Feo V: Medicinal and useful plants in the tradition of Rotonda, Pollino National Park, Southern Italy. J Ethnobiol Ethnomed 2013;23:19.

-49 di Tizio A, Łuczaj TJ, Quave CL, Redži S, Pieroni A: Traditional food and herbal uses of wild plants in the ancient South-Slavic diaspora of Mundimitar/Montemitro (Southern Italy). J Ethnobiol Ethnomed 2012;8:21.

50 Ecevit Genç G, Özhatay N: An ethnobotanical study in Çatalca (European part of Istanbul) II. Turkish J Pharm Sci 2006;3:73-89.

51 Ertu F: An ethnobotanical study in Central Anatolia (Turkey). Economic Botany 2000;54:155-182.

52 González JA, García-Barriuso M, Amich F: Ethnoveterinary medicine in the Arribes del Duero, western Spain. Vet Res Commun 2011;35:283-310.
53 González JA, García-Barriuso M, Gordaliza M, Amich F: Traditional plant-based remedies to control insect vectors of disease in the Arribes del Duero (western Spain): an ethnobotanical study. J Ethnopharmacol 2011;138:595-601.

54 González-Tejero MR, Molero-Mesa J, CasaresPorcel M, Martínez Lirola MJ: New contributions to the ethnopharmacology of Spain. J Ethnopharmacol 1995;45:157-165.

55 Guarino C, De Simone L, Santoro S: Ethnobotanical study of the Sannio area, Campania, Southern Italy. Ethnobotany Research and Applications 2008;6:255-317.

56 Guarrera P, Lucchese F, Medori S: Ethnophytotherapeutical research in the high Molise region (Central-Southern Italy). J Ethnobiol Ethnomed 2008;4:7.

57 Guarrera PM: Traditional antihelmintic, antiparasitic and repellent uses of plants in Central Italy. J Ethnopharmacol 1999;68:183-192.

58 Guarrera PM: Traditional phytotherapy in Central Italy (Marche, Abruzzo, and Latium). Fitoterapia 2005;76:1-25.

59 Guarrera PM, Forti G, Marignoli S: Ethnobotanical and ethnomedicinal uses of plants in the district of Acquapendente (Latium, Central Italy). J Ethnopharmacol 2005;96:429-444.

60 Guarrera PM, Lucia LM: Ethnobotanical remarks on Central and Southern Italy. J Ethnobiol Ethnomed 2007;3:23.

61 Guarrera PM, Salerno G, Caneva G: Folk phytotherapeutical plants from Maratea area (Basilicata, Italy). J Ethnopharmacol 2005;99:367-378.

62 Guarrera PM, Salerno G, Caneva G: Food, flavouring and feed plant traditions in the Tyrrhenian sector of Basilicata, Italy. J Ethnobiol Ethnomed 2006;2:37.

63 Idolo M, Motti R, Mazzoleni S: Ethnobotanical and phytomedicinal knowledge in a long-history protected area, the Abruzzo, Lazio and Molise National Park (Italian Apennines). J Ethnopharmacol 2010;127:379-395.

64 Jari S, Popovi Z, Ma ukanovi -Joci M, Djurdjevi L, Mijatovi M, Karadži B, Mitrovi M, Pavlovi P: An ethnobotanical study on the usage of wild medicinal herbs from Kopaonik Mountain (Central Serbia). J Ethnopharmacol 2007;111:160-175.

65 Kargio lu M, Cenkci S, Serteser A, Evliyao lu N, Konuk M, Kök M, Bag ci Y: An ethnobotanical survey of inner-west Anatolia, Turkey. Hum Ecol 2008;36:763-777.

66 Kargio lu M, Cenkci S, Serteser A, Konuk M, Vural G: Traditional uses of wild plants in the middle Aegean region of Turkey. Hum Ecol 2010;38: 429-450.

67 Koçyi it M, Özhatay N: Wild plants used as medicinal purpose in Yalova (northwest Turkey). Turkish J Pharm Sci 2006;3:91-103.

68 Kozan E, Küpeli E, Yesilada E: Evaluation of some plants used in Turkish folk medicine against parasitic infections for their in vivo anthelmintic activity. J Ethnopharm 2006;108:211-216.

69 Kültür S: Medicinal plants used in Kirklareli Province (Turkey). J Ethnopharmacol 2007;111:341-364.

70 Leporatti ML, Corradi L: Ethnopharmacobotanical remarks on the province of Chieti Town (Abruzzo, central Italy). J Ethnopharm 2001;74:17-40.

71 Leporatti ML, Ghedira K: Comparative analysis of medicinal plants used in traditional medicine in Italy and Tunisia. J Ethnobiol Ethnomed 2009;5:31.

72 Leporatti ML, Impieri M: Ethnobotanical notes about some uses of medicinal plants in Alto Tirreno Cosentino area (Calabria, Southern Italy). J Ethnobiol Ethnomed 2007;3:34.
73 Leto C, Tuttolomondo T, La Bella S, Licata M: Ethnobotanical study in the Madonie regional park (Central Sicily, Italy) - medicinal use of wild shrub and herbaceous plant species. J Ethnopharmacol 2013;146:90-112.

74 Mattalia G, Quave CL, Pieroni A: Traditional uses of wild food and medicinal plants among Brigasc, Kyé, and Provençal communities on the western Italian Alps. Gen Resour Crop Evol 2013;60:587603.

75 Montesano V, Negro D, Sarli G, De Lisi A, Laghetti G, Hammer K: Notes about the uses of plants by one of the last healers in the Basilicata region (South Italy). J Ethnobiol Ethnomed 2012;8:15.

76 Motti R, Antignani V, Idolo M: Traditional plant use in the Phlegraean Fields Regional Park (Campania, Southern Italy). Hum Ecol 2009;37:775-782.

77 Özgökçe F, Özçelik H: Ethnobotanical aspects of some taxa in east Anatolia, Turkey. Economic Botany 2004;58:697-704.

78 Özüdoru B, Akaydin G, Erik S, Yesilada E: Inferences from an ethnobotanical field expedition in the selected locations of Sivas and Yozgat Provinces (Turkey). J Ethnopharmacol 2011;137:85-98.

79 Palmese MT, Uncini Manganelli RE, Tomei PE: An ethno-pharmacobotanical survey in the Sarrabus district (South-east Sardinia). Fitoterapia 2001; 72:619-643.

80 Papp N, Birkás-Frendl K, Farkas A, Pieroni A: An ethnobotanical study on home gardens in a Transylvanian Hungarian Csángó village (Romania). Gen Resour Crop Evol 2012:60:1423-1432.

81 Passalacqua NG, De Fine G, Guarrera PM: Contribution to the knowledge of the veterinary science and of the ethnobotany in Calabria region (Southern Italy). J Ethnobiol Ethnomed 2006;2:52.

82 Pieroni A: Medicinal plants and food medicines in the folk traditions of the upper Lucca Province, Italy. J Ethnopharmacol 2000;70:235-273.

83 Pieroni A, Dibra B, Grishaj G, Grishaj I, Maçai SG: Traditional phytotherapy of the Albanians of Lepushe, Northern Albanian Alps. Fitoterapia 2005;76:379-399.

84 Pieroni A, Giusti ME: Alpine ethnobotany in Italy: Traditional knowledge of gastronomic and medicinal plants among the occitans of the upper Varaita valley, Piedmont. J Ethnobiol Ethnomed 2009;5:32.

85 Pieroni A, Giusti ME, Münz H, Lenzarini C, Turkovi G, Turkovi A: Ethnobotanical knowledge of the Istro-Romanians of Žejane in Croatia. Fitoterapia 2003;74:710-719.

86 Pieroni A, Giusti ME, Quave CL: Cross-cultural ethnobiology in the western Balkans: Medical ethnobotany and ethnozoology among Albanians and Serbs in the Pešter Plateau, Sandžak, South-Western Serbia. Hum Ecol 2011;39:333-349.

87 Pieroni A, Howard P, Volpato G, Santoro RF Natural remedies and nutraceuticals used in ethnoveterinary practices in inland Southern Italy. Vet Res Commun 2004;28:55-80.

88 Pieroni A, Quave C, Nebel S, Heinrich M: Ethnopharmacy of the ethnic Albanians (Arbëreshë) of Northern Basilicata, Italy. Fitoterapia 2002;73: 217-241.

89 Polat R, Satil F: An ethnobotanical survey of medicinal plants in Edremit Gulf (Balikesir-Turkey). J Ethnopharmacol 2012;139:626-641.

90 Popovic Z, Smiljanic M, Matic R, Kostic M, Nikic P, Bojovic S: Phytotherapeutical plants from the Deliblato Sands (Serbia): traditional pharmacopoeia and implications for conservation. Indian J Traditional Knowledge 2012;11:385-400. 
91 Quave CL, Pieroni A, Bennett BC: Dermatological remedies in the traditional pharmacopoeia of Vulture-Alto Bradano, inland Southern Italy. J Ethnobiol Ethnomed 2008;4:5.

92 Rexhepi B, Mustafa B, Hajdari A, Rushidi-Rexhepi J, Quave CL, Pieroni A: Traditional medicinal plant knowledge among Albanians, Macedonians and Gorani in the Sharr Mountains (Republic of Macedonia). Gen Resour Crop Evol 2013: $1-26$.

93 Scherrer AM, Motti R, Weckerle CS: Traditional plant use in the areas of Monte Vesole and Ascea, Cilento National Park (Campania, Southern Italy). J Ethnopharmacol 2005;97:129-143.

94 Schunko C, Grasser S, Vogl CR: Intracultural variation of knowledge about wild plant uses in the biosphere reserve Grosses Walsertal (Austria). J Ethnobiol Ethnomed 2012;8:23.

-95 Tetik F, Civelek S, Cakilcioglu U: Traditional uses of some medicinal plants in Malatya (Turkey). J Ethnopharmacol 2013;146:331-346.

-96 Tuzlac E, Aymaz PE: Turkish folk medicinal plants, part IV: Gönen (Balikesir). Fitoterapia 2001;72:323-343.

-97 Tuzlaci E, Tolon E: Turkish folk medicinal plants, part III: Sile (Istanbul). Fitoterapia 2000;71:673685.

98 Viegi L, Pieroni A, Guarrera PM, Vangelisti R: A review of plants used in folk veterinary medicine in Italy as basis for a databank. J Ethnopharmacol 2003;89:221-244.

-99 Vitalini S, Iriti M, Puricelli C, Ciuchi D, Segale A, Fico G: Traditional knowledge on medicinal and food plants used in Val San Giacomo (Sondrio, Italy) - an alpine ethnobotanical study. J Ethnopharmacol 2013;145:517-529.

100 Vitalini S, Tomè F, Fico G: Traditional uses of medicinal plants in Valvestino (Italy). J Ethnopharmacol 2009;121:106-116.

-101 Vucevac-Bajt V, Karlovi M: Traditional methods for the treatment of animal diseases in Croatia. OIE Revue Scientifique et Technique 1994;13: 499-512.

102 Ye ilada E, Sezik E, Honda G, Takaishi Y, Takeda Y, Tanaka T: Traditional medicine in Turkey IX: Folk medicine in north-west Anatolia. J Ethnopharmacol 1999;64:195-210.

103 WHO Collaborating Centre for Drug Statistics Methodology: ATCvet. www.Whocc.No/atcvet/ atcvet/ (access 01.12.14).

104 Pieroni A, Leimer Price L: Eating and Healing: Traditional Food as Medicine. New York, Food Products Press, 2006.

105 The Angiosperm Phylogeny Group: An update of the Angiosperm Phylogeny Group classification for the orders and families of flowering plants: APG III. Botanical Journal of the Linnean Society 2009;161:105-121.

106 ISO: Iso 3166 country codes, 2014.

107 No authors listed: Council regulation (ec) no. $1804 / 99$ of 19 july 1999 supplementing regulation (ec) no. 2092/91 on organic production of agricultural products and indication referring thereto on agricultural products and foodstuffs to include livestock production. CELEX-EUR 1999;L.222: $1-28$.

108 Gasparetto JC, Martins CAF, Hayashi SS, Otuky MF, Pontarolo R: Ethnobotanical and scientific aspects of Malva sylvestris L.: a millennial herbal medicine. J Pharm Pharmacol 2012;64:172-189.

109 European Scientific Cooperative on Phytotherapy (ESCOP): ESCOP Monographs, ed 2. New York, Thieme, 2003.
110 Vandenbroucke V, Van Pelt H, De Backer P, Croubels S: Animal poisonings in Belgium: a review of the past decade. Vlaams Diergeneeskundig Tijdschrift 2010;79:259-268.

111 Benedek B, Kopp B: Achillea millefolium L. s.l. revisited: recent findings confirm the traditional use. Wien Med Wochenschr 2007;157:312-314.

112 Yakhkeshi S, Rahimi S, Hemati Matin HR: Effects of yarrow (Achillea millefolium L.), antibiotic and probiotic on performance, immune response, serum lipids and microbial population of broilers. J Agr Sci Tech 2012;14:799-810.

113 Baumann JC: Effect of chelidonium, curcuma, absinth and carduus marianus on the bile and pancreatic secretion in liver diseases (in German). Med Monatsschr 1975;29:173-180.

114 Giesecke D, Gunzel R, Hoppe P: Effect of certain organic compounds on saliva secretion in sheep. Arch Int Physiol Biochim 1976;84:129-137.

115 Patra A, Kamra D, Bhar R, Kumar R, Agarwal N: Effect of terminalia chebula and allium sativum on in vivo methane emission by sheep. J Anim Physiol Anim Nutr (Berl) 2011;95:187-191.

116 Haslam E, Lilley TH, Butler LG: Natural astringency in foodstuffs - a molecular interpretation. Crit Rev Food Sci Nutr 1988;27:1-40.

117 Favre JM, Scalbert A, du Penhoat CLMH: Quercus spp. (Oak): In vitro culture and production of tannins; in Bajaj YPS (ed): Medicinal and Aromatic Plants V. Berlin, Springer, 1993, pp 300-312.

118 Ashok PK, Upadhyaya K: Tannins are astringent. J Pharmacognosy Phytochem 2012;1:45-50.

119 Havlickova B, Czaika VA, Friedrich M: Epidemiological trends in skin mycoses worldwide. Mycoses 2008;51:2-15.

120 Ghisalberti EL: Biological and pharmacological activity of naturally occurring iridoids and secoiridoids. Phytomedicine 1998;5:147-163.

121 Stevenson PC, Simmonds MSJ, Sampson J, Houghton PJ, Grice P: Wound healing activity of acylated iridoid glycosides from Scrophularia nodosa. Phytother Res 2002;16:33-35.

122 Tundis R, Loizzo MR, Menichini F, Statti GA: Biological and pharmacological activities of iridoids: recent developments. Mini Rev Med Chem 2008;8:399-420.

123 Clark SP, Bollag WB, Westlund KN, Ma F, Falls G, Xie D, Johnson M, Isales CM, Bhattacharyya MH: Pine oil effects on chemical and thermal injury in mice and cultured mouse dorsal root ganglion neurons. Phytother Res 2014;28:252-260.

124 Sipponen A, Jokinen JJ, Sipponen P, Papp A, Sarna S, Lohi J: Beneficial effect of resin salve in treatment of severe pressure ulcers: a prospective, randomized and controlled multicentre trial. Br J Dermatol 2008;158:1055-1062.

125 Sipponen A, Kuokkanen O, Tiihonen R, Kauppinen H, Jokinen JJ: Natural coniferous resin salve used to treat complicated surgical wounds: pilot clinical trial on healing and costs. Int J Dermatol 2012;51:726-732.

126 Fekih N, Allali H, Merghache S, Chaïb F, Merghache D, El Amine M, Djabou N, Muselli A, Tabti B, Costa J: Chemical composition and antibacterial activity of Pinus halepensis Miller growing in West Northern of Algeria. Asian Pacific Journal of Tropical Disease 2014;4:97-103.

127 Samuelsen AB: The traditional uses, chemical constituents and biological activities of Plantago major 1. A review. J Ethnopharmacol 2000;71:121.
128 Cheng C-1, Wang Z-Y: Bacteriostasic activity of Anthocyanin of Malva sylvestris. J Forest Res 2006;17:83-85.

129 Bonjar S: Evaluation of antibacterial properties of some medicinal plants used in Iran. J Ethnopharmacol 2004;94:301-305.

130 Conforti F, Sosa S, Marrelli M, Menichini F, Statti GA, Uzunov D, Tubaro A, Menichini F, Loggia RD: In vivo anti-inflammatory and in vitro antioxidant activities of mediterranean dietary plants. J Ethnopharmacol 2008;116:144-151.

131 Pirbalouti AG, Yousefi M, Nazari H, Karimi I, Koohpayeh A: Evaluation of burn healing properties of Arnebia euchroma and Malva sylvestris. Electron J Biol 2009;5:62-66.

132 Fall N, Emanuelson U: Milk yield, udder health and reproductive performance in Swedish organic and conventional dairy herds. Journal of Dairy Research 2009;76:402-410.

133 Ivemeyer S, Smolders G, Brinkmann J, Gratzer E, Hansen B, Henriksen BIF, Huber J, Leeb C, March S, Mejdell C, Nicholas P, Roderick S, Stöger E, Vaarst M, Whistance LK, Winckler C, Walkenhorst M: Impact of animal health and welfare planning on medicine use, herd health and production in European organic dairy farms. Livest Sci 2012;145:63-72.

134 Bretzlaff K: Rationale for treatment of endometritis in the dairy cow. Vet Clin North Am Food Anim Pract 1987;3:593-607.

135 Razavi SM, Zarrini G, Molavi G, Ghasemi G: Bioactivity of Malva sylvestris L., a medicinal plant from Iran. Iran J Basic Med Sci 2011;14:574-579.

136 Huang N, Rizshsky L, Hauck C, Nikolau BJ, Murphy PA, Birt DF: Identification of anti-inflammatory constituents in Hypericum perforatum and Hypericum gentianoides extracts using raw 264.7 mouse macrophages. Phytochemistry 2011;72: 2015-2023.

137 Saddiqe Z, Naeem I, Maimoona A: A review of the antibacterial activity of Hypericum perforatum L. J Ethnopharm 2010;131:511-521.

138 Sivula NJ, Ames TR, Marsh WE, Werdin RE: Descriptive epidemiology of morbidity and mortality in Minnesota dairy heifer calves. Prev Vet Med 1996;27:155-171.

139 Saller R, Beschorner M, Hellenbrecht D, Buhring M: Dose-dependancy of symptomatic relief of complaints by chamomile steam inhalation in patients with common cold. Eur J Pharmacol 1990; 183:728-729.

140 Wagner H, Bladt S, Zgainski E: Cardiac Glycoside Drugs; in Wagner H, Bladt S (eds): Plant Drug Analysis. Berlin, Springer, 1984, pp 99-123.

141 Nueleanu V-I: The effect of the unspecific therapy with hellebore (Helleborus purpurascens) on young sheep. Proceedings 43rd Croatian and 3rd International Symposium on Agriculture Opatija Croatia 2008;791:794.

142 Maior MC, Dobrot C: Natural compounds with important medical potential found in Helleborus sp. Cent Eur J Biol 2013;8:272-285.

143 Heckendorn F: Yearly expenses for anthelmintics (all classes even use) for cattle, sheep and goats in europe: Approx. 64,400,000 chf, 2014 (personal communication).

144 Ayaz E, Turel I, Gul A, Yilmaz O: Evaluation of the anthelmentic activity of garlic (Allium sativum) in mice naturally infected with Aspiculuris tetraptera. Recent Pat Antiinfect Drug Discov 2008;3:149-152. 
145 Soh CT: The effects of natural food-preservative substances on the development and survival of intestinal helminth eggs and larvae. I. Action on Ascaris lumbricoides eggs. Am J Trop Med Hyg 1960;9:1-7.

146 Singh TU, Kumar D, Tandan SK, Mishra SK: Inhibitory effect of essential oils of Allium sativum and Piper longum on spontaneous muscular activity of liver fluke, Fasciola gigantica. Exp Parasitol 2009;123:302-308.

147 Zenner L, Callait MP, Granier C, Chauve C: In vitro effect of essential oils from Cinnamomum aromaticum, Citrus limon and Allium sativum on two intestinal flagellates of poultry, Tetratrichomonas gallinarum and Histomonas meleagridis. Parasite 2003;10:153-157.

148 Soffar S, Mokhtar G: Evaluation of the antiparasitic effect of aqueous garlic (Allium sativum) extract in hymenolepiasis nana and giardiasis. $\mathrm{J}$ Egypt Soc Parasitol 1991;21:497-502.

149 Birrenkott GP, Brockenfelt GE, Greer JA, Owens MD: Topical application of garlic reduces northern fowl mite infestation in laying hens. Poult Sci 2000;79:1575-1577.

150 Santos FCC, Monteiro SG, Vogel FSF: Extrato aquoso de alho (Allium sativum) sobre nematóides gastrintestinais de ovinos. Revista Brasileira de Agroecologia 2012;7:139-144.

151 Tariq KA, Chishti MZ, Ahmad F, Shawl AS: Anthelmintic activity of extracts of Artemisia $a b-$ sinthium against ovine nematodes. Vet Parasitol 2009;160:83-88.

152 Amirmohammadi M, Khajoenia S, Bahmani M, Rafieian-Kopaei M, Eftekhari Z, Qorbani M: In vivo evaluation of antiparasitic effects of Artemisia abrotanum and Salvia officinalis extracts on syphacia obvelata, aspiculoris tetrapetra and hymenolepis nana parasites. Asian Pacific Journal of Tropical Disease 2014;4(suppl 1):S250-S254.

153 Gonzalez-Coloma A, Bailen M, Diaz CE, Fraga BM, Martínez-Díaz R, Zuñiga GE, Contreras RA, Cabrera R, Burillo J: Major components of Spanish cultivated Artemisia absinthium populations: antifeedant, antiparasitic, and antioxidant effects. Ind Crop Prod 2012;37:401-407.

154 Buraczewska L, Wasilewko J: Chemical composition including content of amino acids, minerals and alkaloids in seeds of three lupin species cultivated in Poland. J Anim Feed Sci 1999;8:1-12.

155 Edwards O, Singh K: Resistance to insect pests: what do legumes have to offer? Euphytica 2006; 147:273-285.

156 Adhikari KN, Edwards OR, Wang S, RidsdillSmith TJ, Buirchell B: The role of alkaloids in conferring aphid resistance in yellow lupin (Lupinus luteus L.). Crop and Pasture Science 2012;63: 444-451.

-157 George DR, Sparagano O, Port G, Okello E, Shiel RS, Guy J: Environmental interactions with the toxicity of plant essential oils to the poultry red mite Dermanyssus gallinae. Med Vet Entomol 2010;24:1-8.

158 Millar N, Denholm I: Nicotinic acetylcholine receptors: targets for commercially important insecticides. Invert Neurosci 2007;7:53-66.

159 Papazahariadou M, Papadopoulos E, Christaki E, Georgopoulou I, Florou-Paneri P, Tserveni-Goussi A, Yannakopoulos A: Use of Fraxinus ornus as an alternative anti-coccidian in broilers experimentally infected with Eimeria tenella. Revue de Médecine Vétérinaire 2010;161:326-331.
160 Calzada F, Yépez-Mulia L, Aguilar A: In vitro susceptibility of Entamoeba histolytica and Giardia lamblia to plants used in Mexican traditional medicine for the treatment of gastrointestinal disorders. J Ethnopharmacol 2006;108:367-370.

161 Ferreira A, Proenca C, Serralheiro ML, Araujo ME: The in vitro screening for acetylcholinesterase inhibition and antioxidant activity of medicinal plants from Portugal. J Ethnopharmacol 2006; 108:31-37.

162 Sleiman NH, Daher CF: Malva sylvestris water extract: a potential anti-inflammatory and anti-ulcerogenic remedy. Planta Med 2009;75:PH10.

163 Seiberg M, Stone V, Zhao R, Bruning E: Ingestible composition for enhancing elasticity or structural integrity of skin or urogenital tissue of mammal, e.G. human, comprises Cotinus coggygria extract and Malva sylvestris extract: US Patent 20060233898 A1, 2006. https://drive.google.com/ viewerng/viewer? url=patentimages.storage.googleapis.com/pdfs/US20060233898.pdf (access 08.12.2014).

164 Sebai H, Jabri MA, Souli A, Rtibi K, Selmi S, Tebourbi O, El-Benna J, Sakly M: Antidiarrheal and antioxidant activities of chamomile (Matricaria recutita L.) decoction extract in rats. J Ethnopharmacol 2014;152:327-332.

165 Rogosic J, Saric T, Pfister JA, Borina M: Importance of plants with medicinal properties in herbivore diets; in Casasús I, Rogošiç J, Rosati A, Štokoviç I, Gabiña D (eds): Animal Farming and Environmental Interactions in the Mediterranean Region. Wageningen, Wageningen Academic Publishers, 2012, pp 45-56.

166 Kraszewski J, Strzetelski J, Niwinska B: Effects of dietary herb supplements for cows on milk yield and technological quality of milk; in Science EFoA (ed): 55th Annual Meeting of the European Association for Animal Production, 5th-9th Sept 2004. Bled, Slovenia, 2004.

167 Kaithwas G, Majumdar D: Evaluation of antiulcer and antisecretory potential of linum usitatissimum fixed oil and possible mechanism of action. Inflammopharmacology 2010;18:137-145.

168 Jansman AJM, van Wikselaar P, Wagenaars CMF: Effects of feeding linseed and linseed expeller meal to newly weaned piglets on growth performance and gut health and function. Livest Sci 2007;108:171-174.

169 Tafa A, Melaku S, Peters K: Supplementation with linseed (Linum usitatissimum) cake and/or wheat bran on feed utilization and carcass characteristics of arsi-bale sheep. Trop Anim Health Prod 2010;42:677-685.

170 Basch E, Bent S, Collins J, Dacey C, Hammerness P, Harrison M, Smith M, Szapary P, Ulbricht C, Vora M: Flax and flaxseed oil (Linum usitatissimum): a review by the natural standard research collaboration. J Soc Integr Oncol 2007;5:92-105.

171 Swiatek L, Grabias B, Kalembra D: Phenolic acids in certain medicinal plants of the genus Artemisia. Pharmaceutical and Pharmacological Letters 1998;8:158-160.

172 Kreitmair H: Artemisia absinthium L., the true wormwood. Pharmazie 1951;6:27-28.

173 Gilani AH, Janbaz KH: Preventive and curative effects of Artemisia absinthium on acetaminophen and ccl4-induced hepatotoxicity. Gen Pharmacol 1995;26:309-315.

174 Amat N, Upur H, Blažekovi B: In vivo hepatoprotective activity of the aqueous extract of Artemisia absinthium L. against chemically and immunologically induced liver injuries in mice. J Ethnopharmacol 2010;131:478-484.
175 Westphal J, Hörning M, Leonhardt K: Phytotherapy in functional upper abdominal complaints: results of a clinical study with a preparation of several plants. Phytomedicine 1996;2:285-291.

176 Ko YD, Kim JH, Adesogan AT, Ha HM, Kim SC: The effect of replacing rice straw with dry wormwood (Artemisia sp.) on intake, digestibility, nitrogen balance and ruminal fermentation characteristics in sheep. Anim Feed Sci Technol 2006; 125:99-110.

177 Charlebois D: Elderberry as a medicinal plant, in Janick J, Whipkey A (eds): Issues in New Crops and New Uses. Alexandria, ASHS, 2007, 284-292.

178 Jayanegara A, Marquardt S, Kreuzer M, Leiber F: Nutrient and energy content, in vitro ruminal fermentation characteristics and methanogenic potential of alpine forage plant species during early summer. J Sci Food Agric 2011;91:1863-1870.

179 Barak V, Halperin T, Kalickman I: The effect of sambucol, a black elderberry-based, natural product, on the production of human cytokines: I. Inflammatory cytokines. Eur Cytokine Netw 2001; 12:290-296.

180 Ye ilada E, Üstün O, Sezik E, Takaishi Y, Ono Y, Honda G: Inhibitory effects of turkish folk remedies on inflammatory cytokines: Interleukin-1, interleukin-1 and tumor necrosis factor . J Ethnopharmacol 1997;58:59-73.

181 Mascolo N, Autore G, Capasso F, Menghini A, Fasulo MP: Biological screening of italian medicinal plants for anti-inflammatory activity. Phytother Res 1987;1:28-31.

182 Picon PD, Picon RV, Costa AF, Sander GB, Amaral KM, Aboy AL, Henriques AT: Randomized clinical trial of a phytotherapic compound containing Pimpinella anisum, Foeniculum vulgare, Sambucus nigra, and Cassia augustifolia for chronic constipation. BMC Complement Altern Med 2010;10:17.

183 Lemmens-Gruber R, Marchart E, Rawnduzi P, Engel N, Benedek B, Kopp B: Investigation of the spasmolytic activity of the flavonoid fraction of Achillea millefolium s.L. on isolated guinea-pig ilea. Arzneimittelforschung 2006;56:582-588.

184 Cavalcanti AM, Baggio CH, Freitas CS, Rieck L, de Sousa RS, Da Silva-Santos JE, Mesia-Vela S, Marques MC: Safety and antiulcer efficacy studies of Achillea millefolium L. after chronic treatment in wistar rats. J Ethnopharmacol 2006;107: 277-284.

185 Potrich FB, Allemand A, da Silva LM, dos Santos AC, Baggio $\mathrm{CH}$, Freitas CS, Mendes DAGB, Andre E, de Paula Werner MF, Marques MCA: Antiulcerogenic activity of hydroalcoholic extract of Achillea millefolium L.: involvement of the antioxidant system. J Ethnopharmacol 2010;130:85-92.

186 Benedek B, Geisz N, Jäger W, Thalhammer T, Kopp B: Choleretic effects of yarrow (Achillea millefolium s.L.) in the isolated perfused rat liver. Phytomedicine 2006;13:702-706.

187 Hoshino T, Kashimoto N, Kasuga S: Effects of garlic preparations on the gastrointestinal mucosa. J Nutr 2001;131:1109S-1113S.

188 Tomoda M, Gonda R, Shimizu N, Yamada H: Plant mucilages. XLII. An anti-complementary mucilage from the leaves of Malva sylvestris var. mauritiana. Chem Pharm Bull (Tokyo) 1989;37: 3029-3032.

189 European Scientific Cooperative on Phytotherapy (ESCOP): ESCOP Monographs. Supplement 2009, ed 2. New York, Thieme, 2009.

190 Murti K, Panchal MA, Gajera V, Solanki J: Pharmacological properties of Matricaria recutita: a review. Pharmacologia 2012;3:348-351. 
191 World Health Organization (WHO): WHO Monographs on Selected Medicinal Plants, volume 2. Geneva, WHO, 2004.

192 Coelho de Souza G, Haas APS, von Poser GL, Schapoval EES, Elisabetsky E: Ethnopharmacological studies of antimicrobial remedies in the south of Brazil. J Ethnopharmacol 2004;90:135143.

193 Orhan IE, Kartal M, Gülpinar AR, Cos P, Matheeussen A, Maes L, Tasdemir D: Assessment of antimicrobial and antiprotozoal activity of the olive oil macerate samples of Hypericum perforatum and their lc-dad-ms analyses. Food Chem 2013;138:870-875.

194 Öztürk N, Korkmaz S, Öztürk Y: Wound-healing activity of St. John's wort (Hypericum perforatum L.) on chicken embryonic fibroblasts. J Ethnopharmacol 2007;111:33-39.

195 Castro FCB, Magre A, Cherpinski R, Zelante PM, Neves LMG, Esquisatto MAM, Mendonça FAS, Santos GMT: Effects of microcurrent application alone or in combination with topical Hypericum perforatum L. and Arnica montana L. on surgically induced wound healing in wistar rats. Homeopathy 2012;101:147-153.

196 Läuchli S, Hafner J, Wehrmann C, French LE, Hunziker T: Post-surgical scalp wounds with exposed bone treated with a plant-derived wound therapeutic. J Wound Care 2012;21:228, 230, 232 223.

197 Mainetti S, Carnevali F: An experience with paediatric burn wounds treated with a plant-derived wound therapeutic. J Wound Care 2013;22:681682, 684-685, 688-689.

198 Samadi S, Khadivzadeh T, Emami A, Moosavi NS, Tafaghodi M, Behnam HR: The effect of $\mathrm{Hy}$ pericum perforatum on the wound healing and scar of cesarean. J Altern Complement Med 2010; 16:113-117.

199 Gomez-Flores R, Calderon CL, Scheibel LW, Tamez-Guerra P, Rodriguez-Padilla C, TamezGuerra R, Weber RJ: Immunoenhancing properties of Plantago major leaf extract. Phytother Res 2000;14:617-622.

200 Lien C, Lean T, Wen C, Mei-Yin C, Chun-Ching L: Immunomodulatory activities of flavonoids, monoterpenoids, triterpinoids, iridoid glycosides and phenolic compounds of Plantago species. Planta Med 2003;69:600-604.

201 Mahmood A, Phipps M: Wound healing activities of Plantago major leaf extract in rats. Int J Tropical Med 2006;1:33-35.

202 Avancini C, Wiest JM, Dall'Agnol R, Haas JS, von Poser GL: Antimicrobial activity of plants used in the prevention and control of Bovine mastitis in southern Brazil. Latin Am J Pharm 2008;27:894-899.

203 Jarzycka A, Lewi ska A, Gancarz R, Wilk KA: Assessment of extracts of Helichrysum arenarium, Crataegus monogyna, Sambucus nigra in photoprotective UVA and UVB; photostability in cosmetic emulsions. J Photochem Photobiol B 2013; 128:50-57.
204 Hearst C, McCollum G, Nelson D, Ballard LM, Millar BC, Goldsmith CE, Rooney PJ, Moore J, Rao J: Antibacterial activity of elder (Sambucus nigra L.) flower or berry against hospital pathogens. J Med Plant Res 2010;4:1805-1809.

205 Gaultier F, Foucault-Bertaud A, Lamy E, Ejeil AL, Dridi SM, Piccardi N, Piccirilli A, Msika P, Godeau G, Gogly B: Effects of a vegetable extract from Lupinus albus (lu105) on the production of matrix metalloproteinases (MMP1, MMP2, MMP9) and tissue inhibitor of metalloproteinases (TIMP1, TIMP2) by human gingival fibroblasts in culture. Clin Oral Invest 2003; 7 : 198-205.

206 World Health Organization (WHO): Monographs on Selected Medicinal Plants, volume 1. Geneva, WHO, 1999.

207 Tessema B, Mulu A, Kassu A, Yismaw G: An in vitro assessment of the antibacterial effect of garlic (Allium sativum) on bacterial isolates from wound infections. Ethiop Med J 2006;44:385-389.

208 Sidik K, Mahmood A, Salman I: Acceleration of wound healing by aqueous extract of Allium sativum in combination with honey on cutaneous wound healing in rats. Int $\mathrm{J}$ Mol Med Advanced Sci 2006;2:231-235.

209 Parish R, Mcintire S, Heimbach D: Garlic burns: a naturopathic remedy gone awry. Pediatr Emerg Care 1987;3:258-260.

210 Pirbalouti AG, Shahrzad A, Abed K, Hamedi B: Wound healing activity of Malva sylvestris and Punica granatum in alloxan-induced diabetic rats. Acta Pol Pharm 2010;67:511-516.

-211 Süntar I, Akkol EK, Kele H, Oktem A, Ba er KHC, Ye ilada E: A novel wound healing ointment: a formulation of Hypericum perforatum oil and sage and oregano essential oils based on traditional Turkish knowledge. J Ethnopharmacol 2011;134:89-96.

212 Süntar IP, Akkol EK, Yılmazer D, Baykal T, Kırmızıbekmez H, Alper M, Ye ilada E: Investigations on the in vivo wound healing potential of Hypericum perforatum L. J Ethnopharmacol 2010;127:468-477.

213 Zubair M, Ekholm A, Nybom H, Renvert S, Widen C, Rumpunen K: Effects of Plantago major L. leaf extracts on oral epithelial cells in a scratch assay. J Ethnopharmacol 2012;141:825-830.

214 Pirestani A, Galamkari G, Eghbalsaied S, Jafarpour M, Por NG: The effect of Mentha piperita, peppermint and Matricaria chamomilla extracts on agents causing Bovine mastitis in vitro condition. Technical Journal of Engineering and Applied Sciences 2013;24:364-3646.

215 Farideh ZZ, Bagher M, Ashraf A, Akram A, Kazem M: Effects of chamomile extract on biochemical and clinical parameters in a rat model of polycystic ovary syndrome. J Reprod Infertil 2010;11:169.

216 Namjooyan F, Panahi M, Ahmadpour F, Darvish A, Azemi M, Samaee H, Khodayar M: Effect of Matricaria chamomilla L. extract on fetal absorption, placenta structure and liver of diabetic pregnant rats: Planta Med 2011;77:PM184
217 Johari H, Hemayatkhah V, Nikpoor N: The effects of a hydroalcoholic extract of Matricaria chamomilla flower on the pituitary-gonadal axis and ovaries of rats. Int J Endocrinol Metab 2011; 9:330-334.

218 Sharifi F, Simbar M, Mojab F, Majd HA: Comparison of the effects of Matricaria chamomila (chamomile) extract and mefenamic acid on the intensity of premenstrual syndrome. Complement Ther Clin Pract 2014;20:81-88.

219 Sreter T, Szell Z, Varga I: Attempted chemoprophylaxis of cryptosporidiosis in chickens, using diclazuril, toltrazuril, or garlic extract. J Parasitol 1999;85:989-991.

220 Ferreira JFS, Peaden P, Keiser J: In vitro trematocidal effects of crude alcoholic extracts of Artemisia апnиа, A. absinthium, Asimina triloba, and Fumaria officinalis: trematocidal plant alcoholic extracts. Parasitol Res 2011;109:1585-1592.

221 Yildiz K, Ba alan M, Duru O, Gökpinar S: Antiparasitic efficiency of Artemisia absinthium on Toxocara cati in naturally infected cats. Turkiye Parazitol Derg 2011;35:10-14.

222 Zhu L, Dai JL, Yang L, Qiu J: In vitro ovicidal and larvicidal activity of the essential oil of Artemisia lancea against Haemonchus contortus (Strongylida). Vet Parasitol 2013;195:112-117.

223 Caner A, Dö kaya M, De irmenci A, Can H, Baykan , Üner A, Ba demir G, Zeybek U, Gürüz Y: Comparison of the effects of Artemisia vulgaris and Artemisia absinthium growing in western Anatolia against trichinellosis (Trichinella spiralis) in rats. Exp Parasitol 2008;119:173-179.

224 Machado M, Santoro G, Sousa MC, Salgueiro L, Cavaleiro C: Activity of essential oils on the growth of Leishmania infantum promastigotes. Flavour Frag J 2010;25:156-160.

225 Bonsignore L, Loy G, Secci D, Logu AD, Palmieri G: A preliminary microbiological screening of Sardinian plants. Fitoterapia 1990;61:339-341.

226 O'Brien RD: Insecticides. Action and Metabolism. New York, Academic Press,1967.

227 Iqbal Z, Lateef M, Jabbar A, Ghayur MN, Gilani AH: In vitro and in vivo anthelmintic activity of Nicotiana tabacum L. leaves against gastrointestinal nematodes of sheep. Phytother Res 2006;20: 46-48.

228 Zaman MA, Iqbal Z, Abbas RZ, Khan MN, Muhammad G, Younus M, Ahmed S: In vitro and in vivo acaricidal activity of a herbal extract. Vet Parasitol 2012;186:431-436.

229 Magano S, Mkolo M, Shai L: Repellent properties of Nicotiana tabacum and Eucalyptus globoidea against adults of Hyalomma marginatum rufipes. Afr J Microbiol Res 2011;5:4800-4804.

230 Freire R, Borba H, Coelho C: Ruta graveolens 1. Toxicity in Vampirolepis nana infected mice. Indian J Pharmacol 2010;42:345.

231 Iqbal A, Tariq KA, Wazir VS, Singh R: Antiparasitic efficacy of Artemisia absinthium, toltrazuril and amprolium against intestinal coccidiosis in goats. J Parasit Dis 2013;37:88-93.

232 Aggag ME, Yousef RT: Study of antimicrobial activity of chamomile oil. Planta Med 1972;22:140 144. 